\title{
Reflection as a Way to Grapple TPACK Complexity for EFL Teachers
}

\author{
Yunica Rhosiana Sari ${ }^{1}$, Sumardi ${ }^{2}$ \\ ${ }^{1,2}$ University of Negeri Sebelas Maret, Indonesia \\ rhosianasari14@student.uns.ac.id
}

\begin{abstract}
Technological Pedagogical Content Knowledge (TPACK) is a framework to develop the theory to practice in teaching with technology. Therefore, the teacher, as a practitioner of TPACK implementation, has a responsibility to implement the knowledge effectively. This study investigates the meta-cognitive awareness produced by teachers who participate in TPACK lesson design workshops. This process involves some reflection tools, focus group discussion, and reflective journal as a platform for doing the reflection. This study documented teachers' stories during three interviews as they created their TPACK lesson design. The detailed data was from three Indonesian teachers. Those teachers participated in the process of research from the professional development workshop to the focus group interview. The data indicated the details of their experience in reflecting and determining on their professional knowledge. These findings show that during the reflection, the teachers start to realize each aspect of TPACK in three stages. These findings are useful for the government to establish professional development workshops in the technology education field. The researcher explored the implications of this analysis for teachers to effectively design the lesson and future researchers.
\end{abstract}

Keywords

reflection, reflectivepractice, professional development: TPACK

\section{Introduction}

Teachers frequently struggle with unknown problems in classrooms, and solving these problems often involves arts and imagination as well as technical expertise (Schon, 1983) because teaching is a complex profession (Schon, 1983). It leads the teachers to activate their metacognitive tool both as a learner of new circumstances and also a teacher (Loughran, 2007 \& Marcos et al., 2011). Reflection is one of the professional development programs to improve teacher metacognitive development (Jang \& Chen, 2010). Through reflection, the teachers, who face the complexity of bringing technology and information into the classtoom, develop how to elaborate and integrate the concept knowledge of content, pedagogical and technological into a practice of professional development (Jang \& Chen, 2010; So, et al., 2015).

There is also a need for integrating knowledge of technology, pedagogy, and content into an essential framework called TPACK in order to utilize technology effectively (Mishra \& Koehler, 2006). By looking deeper into the aspects formed by TPACK, this framework contains a complex combination of knowledge TPACK (Mishra \& Koehler, 2006). Therefore, in-service teachers need an opportunity to develop TPACK as professional knowledge and deal with those complex aspects (Koh et al., 2015). Since then, reflection is essential strategy for in-service teachers to untie the complex relationship of content, pedagogy, and technology in TPACK development by identifying, analyzing, managing and solving many complex teaching problems especially related to 
TPACK conceptual problems (Spalding \& Wilson, 2002).

\section{Review of Literature}

\subsection{The Process of Reflection in Reflective Practice}

Many studies in the field of professional development explored reflective practice as the crucial topic (Marcos, 2011). It contains a cyclical prcosess including a problem-solving process (Dewey 1910; Lewin 1946; Marcos, 2011; Robertson 2008; Wetzstein and Hacker 2004) by improving teacher's awarness and results on professional knowledge reconstruction (Garmann Johnesen \& Normann 2004; Elliot 1991). The notion of reflective practice, which underpins this study, is understood as "a process that helps teachers think about things happened in the classes, the reason for that thing happened, and future action for the class process (Farrell, 2011). Ghaye (2011) called the process of looking back on their teaching practice as the review process in order to get the projection for the future goals of teaching. Likewise, Burton (2009) states that the review process in reflective practice is a media for teacher in making a future decision which might last longer.

It is an essential component for the teacher because it provides access for the teacher to teacher's works which has less accessible aspects (Farell 2018; Freeman 2016). However, in his study, Mouza (2011) reported that not all of the reflection is equally valuable, which then distinguishes the difference between descriptive and critical reflection. The descriptive reflections emphasized the teacher's experience by describing and recalling what they did. Meanwhile, the critical reflection looked at the relationship between their teaching events and the theoretical principles they represent (Hatton \& Smith, 1995; Lee, 2005). Despite different forms of reflective practice, a reflection is a form of a construct from professional knowledge for teachers (Garmann Johnsen and Normann 2004; Elliot 1991).

\subsection{TPACK in Language Education Field}

Language is an arrangement of arbitrary symbols possessing an agreed upon significance within a community; furthermore, these symbols can be used and understood independent of immediate contexts, and they are connected in regular ways. In line with this definition, therefore, it acceptable to state that language has the great roles in human's lives because it is used as a means of communication among the member of the society. Whatever in a certain ethnics something being conveyed to another person can not be done without the language (Ramlan, 2018). According to Musdiani (2019) the improvement in educational quality strongly emphasizes the importance of the role of the school as an autonomous primary offender and the role of the principal in developing education Before the advent of technology in the education field as a media, teachers focused on content knowledge (CK) and pedagogical knowledge (PK) (So \& Kim, 2009). Technological Pedagogical Content Knowledge (TPACK) appeared to the educational inquiry field as a theoretical framework for recognizing teacher knowledge that is required for technology integration (Mishra \& Koehler, 2006). Many researchers have done a survey related to the TPACK instrument in many skills of language education (Tan et al., 2019). TPACK provides an essential conceptual framework to analyze and evaluate the teacher's needs to integrate technology into teaching. Studies have emphasized the essential of strong conceptual understanding interactions that emerge when designing instruction between technology, pedagogy and content for the teachers (Hofer et al., 2011; Koehler \& Mishra, 2005) as TPACK is a challenge towards the teacher professionalism (Drajati et al., 2019). The conceptual understanding effects on subject matter representation and transformation by considerating on the student's comprehensive 
understanding. It also concerns on how teachers can make teaching materials understandable by students through tacitly designed teaching techniques (So \& Kim, 2009).

Several studies also focus about how this understanding will lead to more successful teaching and learning (Hughes, 2005; Jaipal, 2010; Neiss, 2005). It should be noted that this framework does not include a specific pedagogical preferences; it encourages the use of a range of teaching and learning approaches (Harris \& Hofer, 2011). Schmidt et al. (2009b) mentions the combination of those three main aspects into a construct. The construct is pedagogical content knowledge (PCK), the knowledge of subject content of the teaching mechanism (Shulman, 1986); Technological content knowledge (TCK), a knowledge construct on how technology creates new depictions for particular content; technological pedagogical knowledge (TPK), how various technologies utilized in teaching, and how technology affected the way teachers teach;and last, technological pedagogical content knowledge (TPACKa knowledge construct needed by teachers when trying to integrate technology into their pedagogy in any subject area of content. (Schmidt et al., 2009b).

Recent studies have shown a professional development program for the teacher could add a knowledge bases theoretically on TPACK (Jang \& Chen, 2010), also a study has investigated that tele-collaboration as a way to boost pre-service teacher practice TK development and made them focus on some aspects in TPACK (Bueno-Alastuey et al., 2018). In this study, reflection was a way to make in-service teachers exploring their practice and finding out what has been improved in their TPACK Practice. Through thematic analysis of the interviews, a question was explored in this study: How did reflection help teachers to construe their TPACK Practice?

\section{Research Methods}

\subsection{Participant}

The participants were thirty-six in-service English teachers implementing TPACK on Senior High school in Indonesia. Ten teachers joined third times of focus group discussion. However, three teachers, namely Ferni, Juna, and Leni, were chosen under some particular considerations that are convenient for this study that is the participants conducted reflection and utilizing the TPACK model until the end of the projects. Besides, the things considered were in-service teachers who have joined three times workshops of TPACK. It has six hours of practice in each workshop. The researcher used the document in the form of a lesson plan, poster documentation, and reflective journals of the participants. The researcher used the participant's lesson plan they used in their daily teaching. While teacher's reflective journals or poster documentation contained their stories in teaching.

\subsection{Procedure}

In this study, the researcher conducted a thematic analysis in narrative inquiry focusing on ordering on teacher's experience story about their input in conducting reflection during TPACK implementation. Narrative inquiry in this study is a research design used in a vast field of research: technology and education. The researcher collected data from three interviews over a semester. Each interview took ninety minutes. The purpose of the interviews is to follow up on what happened during the classroom process before and after the TPACK implementation. The purpose of these interviews was to ensure the teacher state and describe clearly her reflections on teaching utilizing technology. The researchers recorded the interviews used for this study on audio recorder and then transcribed it. The teachers approved to write their views about lessons to use as a journal entry at the end of each day. The teachers were allowed to write many words she expected in answering the 
questions or any other views she might have had. The researcher used the thematic analysis: a multiple case study to analyze the narrative data in this research. Barkhuizen proposes the model of thematic analysis (Barkhuizen, Benson and Chik, 2014), whereby it contains three activities: 1) repeatedly reading of the data, 2) coding and categorizing the data extracts, and 3) recognizing the thematic headings.

\section{Discussion}

Necessarily, reflective practice can lead the teachers to be critical to their practice. However, he/she must take to an account of TPACK as the framework to be effective in teaching using technology. Concerning some aspects of TPACK, the integration between content, pedagogy, and technology. The interviews analysis focused on investigating how reflection helped the participants consider each element in TPACK; meanwhile, the reflective journals focused in what way the in-service teachers scrutinizing their perceptions with technology adoption by looking at the facets of pedagogy, content and technology.

First, the participants started to recognize the essential relation between technology and pedagogy. The participants elaborated their views or their reasons of the reflection advantageousness for technology integration in case of their teaching practice to grasp how reflection helped the participants develop TPACK. There are some perspectives described by the participants about how far they have already implemented technology integration in the lens of the TPACK framework. From the interviewed taken by both of the participants, the participants thought about the past experienced of their implementation.

Last year, I still did not understand in utilizing technology effectively by thinking about its relationship to pedagogy and material, so it needs to be fixed again, especially the material. Because the material was still not as deep as needed. Yesterday I was more concerned with using technology. It might be $40 \%$ technology, $30 \%$ content, and the rest was pedagogical. So it is not too pedagogy. So pedagogy might be a bit less balanced. (Juna, 2019)

From Juna's reflection about his experience in implementing TPACK as a framework, Juna elaborated on how far that he has implemented a TPACK framework on his technology integration in the classroom. From his statement, he focused on technological needs (TK). Meanwhile, he stated that pedagogy or how he brought the technology into the classroom in specific material (PCK) is only the rest of TK. A consideration in technological needs for specific materials showed that he could recognize the elements needed in technology integration by rethinking about his experience. The narrative revealed that reflection in-service EFL teachers helped them to develop their TPACK implementation.

Meanwhile, from Ferni, TK is the element that needs to be improved; here is Ferni narrative:

I am still less in an exploration of technology. I need to have a willingness to explore if I want to improve TPACK. It is sometimes a trial and error. It means that if I get a brilliant idea, I need to run the idea first. Well, I rarely find professional development workshops, especially in technology usage, which means exploring it, for example, what should I do or how should I do is still lack of trial. In my experience, technology in learning, if we have not tried it ourselves, we cannot use the idea. For example, I once made a quiz using Kahoot, oh this is good, it is using Kahoot. Because I have tried it already, but if someone who has not tried Kahoot, they cannot use Kahoot. Even though it is entertaining. So I do not explore because I still have a lack of understanding of IT. (Ferni,2019) 
Ferni, in her experiences, stated that technological knowledge is the essential element of the TPACK framework. To understand the development of IT, so that she can get the appropriate technology for the materials, she said that technology exploration is needed. In her example, she mentioned Kahoot as the technology which is integrated into the content or assessment. Her statement indicates that she believed between technology and content integration needs exploration of technology first before TK (Park \& Oliver, 2008). It is derived through study and research on experienced teachers in high school, stating that PCK is indeed a body of knowledge that involves both comprehension and implementation. The teachers reconstructed and combined various PCK elements by reflection-in-action (during teaching) and reflection-on-action (after teaching).

She reflected the context of specific workshops or the trial or error itself to make a fresh idea. This study points to the need for looking more closely into the relationship between teachers' deficit theorizing related to their reflection towards the technology use. Findings from this work demonstrated that teachers acquired TPACK, but many of them had difficulty applying it in action in innovative ways for the student as cited on So, et al., 2015, it may be caused by the different factors of applying technology between the teacher and the student. Other researchers have also distinguished between the knowledge that teachers possess and the knowledge they use in action (Doering et al., 2009).

Secondly, the teachers were mostly confident about technology use in classrooms. They started to understand the complexity of technology integration in the local curriculum. For example, Ferni concerns the materials and students' life.

What kind of things that I can use, for example, when I want to use those videos as the activity, so I have to find some in TED-Ed. I will find different kinds of videos. Then, it is about the students' life. So I usually create a project that is in line with the students' life. When we have to decide what the students' should do, like in bullying, they can see bullying around their life. So after that, I always try to relate the activity to the students' life. (Ferni,2019)

She believed learning a foreign language is not only talking about the theories and projects. It is about how the project itself can relate to the student's life. The teachers may be easy to find a source to integrate their knowledge on content and technological aspects, but in this case, to combine between the goals of curriculum and students' life is another challenge for the teachers not easy to pick a source and let it go without meaning. Further, she describes her concerns on making a video as a simple thing means that doing a project to combine between the technology and context might make the students confused. She mentioned that technology could be used to teach a particular material or topic. From Schmidt et al. (2009), this relates to the awareness of technology and content knowledge (TCK), then she told how and why she utilized technology appropriately with a particular strategy. She decided to simplify her instruction to make students did the projects; in this case, her pedagogy aspects are elaborated as a challenge.

I should think about what the students can do dealing with the projects. For example, when I ask them to make tips in the form of video, I have to consider making a video in a simple thing considering the student's understanding and using the time effectively. (Ferni, 2019)

Juna mentioned a similar point of view in his reflection about the positive view of technology media in the classroom. He reflected on the local curriculum affected in the use of technology decisions. Meanwhile, he elaborated that appropriate technology usage affects pedagogy effectiveness.

At the end of the lesson, I realized that I positively agree that technology helps me to improve my time efficiency. This happened when I applied poetry maker and made it into a video, so they need to upload it online. I did not need work hours to collect their work, but they can collect it for twenty-four hours! Somehow, in poetry maker 
application, I need to adjust the topic closer to the local topic because online application seems to have a western curriculum (Juna, 2019)

The effectiveness is in the form of time management for the assesemnet process. He mentioned that he realized in the end of the lesson. It means that in the end of the lesson he rethinking about teaching and learning process. Similar to Ferni's reflection, Juna also emphasized to the time management effectiveness. Juna's narrative also has the same point with Ferni's reflection about local curriculum. Therefore, through the reflection, the teachers recall their memory step by step of their teaching practice with technology and mention what they have learned dealing with technology as the media in the teaching process. As predicted in the literature by Farrell (2018), the teacher grows their understanding by describing and elaborating their instructional process that happened in class will develop their understanding of teaching with technology. Describing and elaborating the process is also a useful step for the next successful application of knowledge (Farrell, 2018). Further, by noticing the words ' $I$ have to consider that making a video in a simple thing' as a narrative implied the complexity of technology toward pedagogy knowledge. Technology affects on teacher's strategy in order to be understandable.

The third thing is after surveying the effective way of technology usage in a model lesson, The participants were capable of articulating their experience of technology adoption by narrating their findings orally in the interviews. Both of the All participants insisted upon the helpfulness of creating reflective journals. They explained that reflection is a media to recall everything they observed in classroom and to reflect on how to implement what they learned or plan for their future classroom. For example, Leni said, "so because the journal is in written form, I can reread it. I found that I lack knowledge in this matter. I am planning, or less trying, less brave. Those are the benefits". Leni also reported that by writing more about their classroom experience, their views or their problems, reflection became even more analytical and profound in her class experiences.

The reflection is useful for helping me remember what happened in class until the next days. It feels fresh every day, so it helps me to be aware of problems or possibilities in integrating technology and materials. For example, I look back and learn the portfolio I made. Moreover, we do not need to repeat the problem we faced last semester because we can learn it from the reflective journal. For example, "I got the problem in these materials to be combined with this application," or when my students forgot to bring a charger for their class last week, I can remember it through reading the reflective journal. Then if there is a teacher change when I can not teach in class, it looks like it is useful too. (Leni, 2019)

Further, Leni explained that he could learn the problem from a reflective journal. She mentioned her problem with the material integration to the application media or the technology. It belongs to content and technological knowledge (TCK) problem. Another challenge faced by Leni is about students' readiness by pointing to the students who forget to bring a charger, it is reported that reflective practice indicates that the teacher must deal with any challenge and can evaluate whether he/she has given the meaningful change of learning by reading the reflective journal. Syahputri (2019) states Reading is central to the learning process. By reading activity, people may gain important that is not presented by teachers in the classroom. The reader is an active participant who has an important interpreive function in the reading process.

The findings revealed that by writing a reflective journal, the participants can remember what has been done during the implementation of the TPACK framework and pushed them to think about what happened in the classroom in-depth. Sometimes the teacher found some obstacles, whether it is a technical and non-technical problem (Drajati et al., 2018). This also 
relates to literature, which mentions about writing reflective journals narratively helped the teachers to be confident to do their actions in the classroom (Ford, 2016). This situation also relates to Farrell (2018), who reported that the goals of being a reflective teacher are constructing new learning based on the previous experience and introspection to the previous learning. Moreover, this will lead them to practical use in the future. In findings, one of the participants telling about "not repeating the problem in the future," as the future indicates the reflection mentioned by Schön (1983).

Besides to have a meaningful change in technology learning, by doing the group reflection, the teachers are more sensitive and aware, but also more open-minded and reflective in technology mediated teaching. Juna said:

Group reflection is useful. We can know and see other experiences from friends' experiences. For example, I use TED. Ed in other materials, not only what I thought before. Maybe something I do not know, I know it from the reflection activity. Then, besides knowing people's experiences, number two is exploring possibilities. "Oh, it turns out that it works like this?" "Oh, this is why getting a suggestion is not boring, just make a dialogue." I replace making video tips. How to find a solution for bullying, "oh yeah, that means giving suggestion does not have to be done, let us make it keep on collecting" but make tips, then the tips are posted on that. So it is possible. (Ferni, 2019)

In the above quotes, Ferni explained how their views evolved from group reflection. She gets many possibilities in applying technology to certain materials. She mentioned the materials about suggestion is always being taught conventionally, then after thinking about the possibilities told by her friends in the discussion, it turns out that she can accept the different way in teaching the materials. She thought that in-service teachers were required to have excellent skills in teaching English when they needed to apply 'teaching students' rather than 'teaching the materials.' Accordingly, Ferni shared his experience relating to improving his skill in teaching English by joining the reflective discussion both on social media or direct discussion. Another impact on writing a reflective journal and peer discussion stated by Ferni that she proved the aspect of open-mindedness by Dewey (1933). In her narrative, she has a desire to listen to many possibilities that happened in teaching with technology. Those possibilities involve the way, the source, and the impacts for the students. She thinks broader in teaching with technology. Just like the teachers expect students be active learners (Manning \& Payne, 1993; Randi, 2004), meanwhile teachers must also be involved throughout the teaching cycle, keeping an eye on the success of the course materials and listening to colleagues ' recommendations and input from students to refine their instructional materials and techniques.

From the above story, in-service teachers realized to teach students rather than teach the materials only. They needed to be aware of some aspects, not only technology, without considering many things. This statement relates to directness criteria as being a reflective teacher. By implementing directness, in-service teachers understood that they first should find out what aspect needed to be improved. In Kramarski and Michalsky's (2010) study, Metacognitive help for reflective questions supported pre-service teachers to track and assess their problem-solving processes; in addition, this encouragement enabled them to consider different viewpoints and principles for moving information from primary to high-order design skills, reflecting the development of PCK attendees.

The finding also The results also showed that meditation in their prospective classes encouraged the participants to talk on how to implement everything they acquired. From the interviews recorded, in this regard, the reflections mentioned by the participants were helpful for their learning. Based on Mouza (2011), the reflection did by the participants portrayed mostly descriptive reflection. In order to plan for the next lecture, it was important to go 
through those levels of reflection. The teachers have significant chances to apply in realworld curriculum of what they learned in the technology integration program, but time allocation, as revealed as the issue of reflection, made them think twice to apply it immediately. Thus, reflection, the act of creation, provided the teachers an opportunity to check in their thoughts about the concepts of technology integration they had learned in the workshop. Also, having played with the theories in her brain, IST-1 looked to be more comfortable in utilizing technology to instruct. Lee (2010) have observed that conducting reflective journals enables teachers become more confident in teaching. This phenomenon also happened to EFL novice instructor in a study by Yoshihara, Kurata and Yamauchi (2019).

\section{Conclusion}

By conducting thematic analysis of the in-service teachers interviews transcript, the researcher proved reflection facilitated in-service teachers recalling their memories about what they have learned by elaborating and potraying the aspects of the TPACK stage by stage. First, teachers are aware of pedagogy and technology. After that, their reflection comes to the curriculum, which means the local content needed by the students. Finally, the teachers agree that many tools of reflection, especially reflective journal facilitates them to have a deeper consideration an how to implement their knowledge reconstruction in their future classrooms, and simplify the way to be more reflective and open-minded in teaching with technology. There are differences between Ferni and Leni as the experienced teachers, in the reflection, they emphasized the materials in their reflection, the teachers also mentioned that the way of innovatively bringing the technology seems to be difficult for them. Meanwhile, for Juna as a novice teacher, he rarely reflected the materials or the teaching strategy. Further, the contribution of this study of reflection is improving teaching performance by making them realized some parts that need to be focused, which will help them a lot in considering the materials, strategy, and technology and putting them in the lesson plan.

\section{References}

Barkhuizen, G. P. , Benson, P., \& Chik, A. (2014). Narrative Inquiry in Language Teaching and Learning Research. New York: Routledge

Chai, C. S., Tan, L., Deng, F., \& Koh, J. H. L. (2017). Examining pre-service teachers' design capacities for web-based 21st-century new culture of learning. Australasian Journal of Educational Technology, 33(1), 1-20. https://doi.org/10.14742/ajet.3013

Chai, C., S. \& Koh, J. H. L. (2017) Changing teachers' TPACK and design beliefs through the Scaffolded TPACK Lesson Design Model (STLDM), Learning: Research and Practice, 3(2), 114-129, DOI: 10.1080/23735082.2017.1360506

Dewey, J. (1910). How we think. London: D.C.Heath

Dewey, J (1933) How We Think: A Restatement of the Relation of Reflective Thinking to the Educative Process; D.C. Heath and Company: Lexington, MA, USA.

Doering, A., Veletsianos, G., Scharber, C., \& Miller, C. (2009). Using the technological, pedagogical, and content knowledge framework to design online learning environments and professional development. Journal of Educational Computing Research, 41(3), 319-346. DOI:10.2190/EC.41.3.d

Drajati, N., Tan, L., Haryati, S., Rochsantiningsih, D., \& Zainnuri, H. (2018). Investigating English language teachers in developing TPACK and multimodal literacy. Indonesian Journal of Applied Linguistics, 7(3), 575-582. DOI: /10.17509/ijal.v7i3.9806 
Elliot, J. 1991. Action research for educational change. Buckingham: Open University Press.

Farrell, T. S. C. (2011). "Keeping SCORE": Reflective Practice Through Classroom Observations. RELC Journal, 42(3), 265-272. doi:10.1177/0033688211419396

Farrell, T.S.C. (2018). Operationalizing Reflective Practice in Second Language Teacher Education. Journal of Second Language Teacher Education, Vol. 1 (1), 1-20

Ford, K. (2016). The taped monologue as narrative technique for reflective practice. ELT Journal, 70(3), 253-260. doi:10.1093/elt/ccv079

Freeman, D. (2016). Educating second language teachers. Oxford, UK: Oxford University Press.

Garmann Johnsen, H.C., and Normann, R. (2004). When research and practice collide: The role of action research when there is a conflict of interest with stakeholders. Systemic Practice and Action Research 17, no. 3: 207-35.

Hughes, J. (2005). The role of teacher knowledge and learning experiences in forming technology-integrated pedagogy. Journal of Technology and Teacher Education, 13(2), 227-302.

Harris, J., \& Hofer, M. J. (2011). Technological pedagogical content knowledge (TPACK) in action: A descriptive study of secondary teachers' curriculum-based, technology-related instructional planning. Journal of Research on Technology in Education, 43, 211-229.

Hofer, M. J., Grandgenett, N., Harris, J., \& Swan, K. (2011). Testing a TPACK-based technology integration observation instrument. In M. Koehler \& P. Mishra, (Eds.) Proceedings of Society for Information Technology \& Teacher Education International Conference 2011 (4352-4359). Chesapeake, VA: AACE.

Jaipal, K., \& Figg, C. (2010b). Unpacking the "Total PACKage": Emergent TPACK characteristics from a study of preservice teachers teaching with technology. Journal of Technology and Teacher Education, 18(3), 415-441

Jang, S.-J., \& Chen, K.-C. (2010). From PCK to TPACK: Developing a Transformative Model for Pre-Service Science Teachers. Journal of Science Education and Technology, 19(6), 553-564. doi:10.1007/s10956-010-9222-y

Koh, J. H. L., Chai, C. S., Wong, B., \& Hong, H.-Y. (2015). Design thinking and 21stcentury skills. In J. H. L. Koh, C. S. Chai, B. Wong \& H.-Y. Hong (Eds.) Design Thinking for Education: Conceptions and Applications in Teaching and Learning (pp. 33-46). Singapore: Springer Singapore.

Kramarski, B., \& Michalsky, T. (2010). Preparing preservice teachers for self-regulated learning in the context of technological pedagogical content knowledge. Learning and Instruction. 20, 434-447.

Lee, Okseon. (2010). Facilitating preservice teachers' reflection through interactive online journal writing. Physical Educator. 67. 128-139.

Loughran, J. (2007). Researching teacher education practices: Responding to the challenges, demands, and expectation on self-studies. Journal of Teacher Education 58 (1),12-20.

Lewin, K. (1946) Action Research and Minority Problems, in G. W. Lewin (Ed.) Resolving Social Conflicts. New York: Harper \& Row.

Manning, B. H., \& Payne, B. D. (1993). A Vygotskian-based theory of teacher cognition: Toward the acquisition of mental reflection and self-regulation. Teaching and Teacher Education, 9(4), 361-371.

Marcos, J., Sanchez, E. \& Tillema, H.H. (2011). Promoting teacher reflection: what is said to be done. Journal of Education for Teaching: International research and pedagogy, 37(1), 21-36

Mishra, P., \& Koehler, M. (2006). Technological pedagogical content knowledge: A framework for teacher knowledge. Teachers College Record, 108, 1017-1054. 
Mouza, C. (2011). Promoting Urban Teachers' Understanding of Technology, Content, and Pedagogy in the Context of Case Development. Journal of Research on Technology in Education, 44(1), 1-29. DOI:10.1080/15391523.2011.10782577

Musdiani, et al. (2019). Analysis the Role of Headmaster in Applying Quality of Education in Primary School Districts, Aceh Barat. Budapest International Research and Critics in Linguistics and Education (BirLE) Journal, 27-35.

Neiss, M. L. (2005). Preparing teachers to teach science and mathematics with technology: Developing a technology pedagogical content knowledge. Teaching and Teacher Education, 21(5), 509-523.

Park, S., \& Oliver, J. S. (2007). Revisiting the Conceptualisation of Pedagogical Content Knowledge (PCK): PCK as a Conceptual Tool to Understand Teachers as Professionals. Research in Science Education, 38(3), 261-284. DOI:10.1007/s11165007-9049-6

Ramlan. (2018). Language Standardization in General Point of View. Budapest International Research and Critics Institute-Journal (BIRCI-Journal), 27-33.

Randi, J. (2004). Teachers as self-regulated learners. Teacher College Record, 106(9), 18251853.

Robertson, J.M. 2008. Coaching educational leadership: Building leadership capacity through partnership. London: Sage.

Schon, D. (1983) The Reflective Practitioner: How Professionals Think in Action. New York: Basic Books

So, Hyo-Jeong \& Kim, Bosung. (2009). Learning about problem-based learning: Student teachers integrating technology, pedagogy, and content knowledge. Australasian Journal of Educational Technology. Vol 25(1), 101-116

So, H-J., Choi, H., \& Yoon, H-G. (2015) 'Understanding users' perceived needs and concerns toward mobile application integration in primary science education in Korea', Int. J. Mobile Learning and Organisation, Vol. 9, No. 4, pp.315-333

Schön, D.A. (1983).The Reflective Practitioner: How Professionals Think in Action; Basic Books: New York, NY, USA.

Spalding, E. \& Wilson, A. (2002) Demystifying Reflection: A study of pedagogical strategies that encourage reflective journal writing, Teachers College Record, 104:7, pp. 139-421

Spalding, E. \& Wilson, A. (2002) Demystifying Reflection: A study of pedagogical strategies that encourage reflective journal writing, Teachers College Record, 104:7, pp. 139-421

Spalding, E. \& Wilson, A. (2002). Demystifying Reflection: A study of Pedagogical Strategies that Encourage Reflective Writing, Teachers College Record. 104: 7, 139 421

Syahputri, D. and Mariyati, P. (2019). Improving Students' Achievement in Reading Comprehension by Applying Contextual Teaching and Learning (CTL). Budapest International Research and Critics in Linguistics and Education (BirLE) Journal, 58-69.

Tan, L., Chai, C-S., Deng, F., Zheng, C. P. \& Drajati, N. A. (2019): Examining pre-service teachers' knowledge of teaching multimodal literacies: validation of a TPACK survey, Educational Media International, DOI: 10.1080/09523987.2019.1681110

Yoshihara, R., Kurata, A., \& Yamauchi, A. (2019) Reflective journals to explore struggles and difficulties of novice Japanese EFL university instructors. Reflective Practice, DOI: 10.1080/14623943.2019.1708714. 